\title{
ANALISIS OPTIMALISASI PRINSIP LEMBAGA KEUANGAN SYARIAH NON-BANK “ANOMALY EVENT STUDY JANUARY EFFECT TERHADAP ABNORMAL RETURN SAHAM SYARIAH (JII) DI PASAR MODAL INDONESIA"
}

\author{
Nurul Susianti \\ Fakultas Ekonomi dan Bisnis Islam UIN Mataram
}

\begin{abstract}
Abstrak
Penelitian dalam paper ini menggunakan penelitian kuantitaif dengan metode deskriptif dan uji beda paired t test tentang analisis optimalisasi prinsip Lembaga Keuangan Syariah Non-Bank yang mengukur tingkat abnormal return saham syariah di pasar modal syariah, Fokus masalah dalam penelitian ini adalah pengamatan sebelum january effect dan sesudah january effect, yakni minggu terakhir pada bulan desember dan awal minggu january effect. hasil penelitian ini menunjukan bahwa sebelum dan sesudah January Effect menunjukkan bahwa nilai $\mathrm{t}-1$ dan $\mathrm{t}+1$ sampai $\mathrm{t}-6$ dan $\mathrm{t}+6$ menunjukkan nilai yang diterima karena menghasilkan nilai signifikasi kurang dari 0,05, artinya ada perbedaan secara signifikan selama 6 hari baik sebelum dan sesudah January Effect. Hasil penelitian ini bertentangan dengan prinsip-prinsip lembaga keuangan syariah baik bank maupun non-bank, seperti, Pelaksanaan transaksi harus dilakukan menurut prinsip kehati-hatian serta tidak diperbolehkan melakukan spekulasi dan manipulasi yang di dalamnya mengandung unsur dharar, gharar, riba, maisir, risywah, maksiat dan kezhaliman. Salah satu penyebab terjadinya abnormal return pada event studi january effect bertentangan dengan fatwa MUI sehingga Abnormal return yang terjadi sebelum dan sesudah januar effect tidak sesuai dengan prinsip-prinsip lembaga keuangan syariah nonbank.
\end{abstract}

Kata Kunci: Prinsip Lembaga Keuangan Syariah, Saham Syariah, JII, dan Abnormal Return. 


\section{A. PENDAhuluan}

Lembaga keuangan syariah adalah lembaga yang mengelola keuangan dana pihak ketiga, baik dalam bentuk bank maupun non bank. Istilah pasar biasanya digunakan istilah bursa, exchange dan market. Sementara untuk istilah modal sering dugunakan istilah efek securities, dan stock. Pasar modal menurut Undang-Undang No.8 tahun 1995 tentang pasar modal pasal 1 ayat 12 adalah kegiatan yang bersangkutan dengan penawaran umum dan perdagangan efek, perusahaan publik yang berkaitan dengan efek yang diterbitkannya, serta lembaga dan profesi yang berkaitan dengan efek. Melalui pasar modal syariah dikenal juga dengan nama bursa efek. Bursa efek menurut pasal 1 ayat 4 UU No. 8 tahun 1995 tentang pasar modal adalah pihak yang menyelenggarakan dan menyediakan sistem dan/atau sarana untuk mempertemukan penawaran jual dan beli efek pihak-pihak lain dengan tujuan memperdagangkan efek diantara mereka. Bursa efek di Indonesia dikenal Bursa Efek Jakarta (BEJ), Bursa Efek Surabaya (BES). Belakangan, tanggal 30 oktober 2007 BES dan BEJ sudah dimarger dengan nama bursa Bursa Efek Indonesia (BEI). Sehingga dengan demikian hanya ada satu pelaksanaan Bursa Efek di Indonesia, yaitu BEI. Sedangkan bagi pasar modal syariah, listing-nya-dilakukan di Jakarta Islamic Indeks yang telah di luncurkan sejak 3 juli 2000. ${ }^{1}$

${ }^{1}$ Andri Soemitri, Bank dan Lembaga Keuangan Syariah(Jakarta:PRENADA MEDIA GROUP, 2009), hlm 111
Perdebatan tentang pasar yang efisien masih sering terjadi sampai saat ini. Satu sisi terdapat banyak penelitian memberikan bukti empiris yang mendukung konsep pasar yang efisien. Sisi lain muncul sejumlah penelitian yang menyatakan adanya anomali pasar yang sering muncul dalam pasar modal syariah ataupun pasar modal konvensional. Anomali tersebut sering berdampak buruk pada pasar modal yang bersangkutan karena menyebabkan pasar modal tidak lagi menampilkan keadaan ekonomi yang sebenarnya. Fenomena anomali yang sering muncul adalah, January Effect, size effect, serta day ofthe week effect. Teori lain menyebutkan bahwa January Effect adalah kecendrungan naiknya harga saham antara 31 Desember sampai dengan akhir minggu pertama bulan Januari. ${ }^{2}$

January effect terjadi karena investor atau emiten menjual saham-saham yang dimiliki dengan harga yang murah di akhir tahun atau seminggu sebelum dan sesudah tahun baru untuk memperbaiki laporan keuangan dan keuntungan perusahan atau emiten. Pendekatan yang digunakan dalam penelitian ini adalah Studi peristiwa (Event Studi) yang merupakan alat analisis return yang tidak normal (Abnormal return) dari sekuritas yangmungkin terjadi disekitar pengumuman dari suatu peristiwa.

${ }^{2}$ Wiwit Rahyuningsih "Pengaruh January Effect Dan Size Effect Terhadap Return Saham Di JII Tahun 2010-2013" Jurnal Fakultas Ekonomi Jurusan Manajemen, UIN Malang. 2013, hlm. 4. 


\section{B. RUMUSAN MASALAH}

Berdasarkan latar belakang diatas, peneliti merumuskan fokus kajian masalah terkait optimalisasi penerapan prinsip syariah di lemabga keuangan syariah non bank terhadap penomena anomaly January effect di pasar modal syariah yang mempengararuhi efesiensi pasar modal Indonesia, adalah sebagai berikut:

Sejauh mana optimalisasi penerapan prinsip-prinsip oprasional lembaga keuangan syariah non-bank sebelum dan sesudah January effect terhadap Abnormal Return saham syariah Jakarta Islamic Indeks (JII) di pasar modal Indonesia?

\section{LANDASAN TEORI DAN PENGEMBANGAN HIPOTESIS}

\section{Telaah Pustaka}

Penelitian rujukan pertama, Maliasari ${ }^{3}$ dan Nursanti ${ }^{4}$ yangmembahas tentang Pengaruh January Effect Dan Rogalski Effect Terhadap Abnormal Return, dan mencoba membandingkan perbedaan january effect dan rogalsky effect pada perusahaan yang tergabung dalam jakarta islamic index di bursa efek indonesia tahun 2011 - 2013 pada Saham Dan Trading Volume Activity Jenis

${ }^{3}$ Karina Maliasari "Pengaruh January Effect Dan Rogalski Effect Terhadap Abnormal Return Saham Dan Trading Volume Activity (Studi Pada Perusahaan LQ45 yang Terdaftar di Bursa Efek Indonesia)" Tesis, Fakultas Ekonomi dan Bisnis, Universitas Brawijaya Malang 2013, hlm. 1-14

${ }^{4}$ Devita Nursanti, "Analisis Perbedaan January Effect Dan Rogalsky Effect Pada Perusahaan Yang Tergabung Dalam Jakarta Islamic Index Di Bursa Efek Indonesia Tahun 2011-2013"Jurnal Akuntansi dan Sistem Teknologi InformasiFakultas Ekonomi Universitas Slamet Riyadi Surakarta. Vol. 11 Edisi Khusus Desember 2015, hlm. 1-11 penelitian ini adalah event study. Hasil pengujian January Effect dengan metode uji Kruskall-Wallis, membuktikan bahwa fenomenaJanuaryEffect tidak terjadipada indeks LQ45 BEI periode 2011. Hasil pengujian Rogalski Effect dengan metode Paired Sample t-Test membuktikan bahwa abnormal return saham Senin di bulan Januari menunjukkan adanya perbedaan tetapi tidak signifikan sehingga mengindikasikan tidak ditemukannya fenomena Rogalski Effect pada indeks LQ45 BEI baik periode 2011 maupun 2012. Perbedaan penelitian ini adalah meninjau penerapan prinsip syariah terhadap lembaga keuangan syariah berdasarkan anomaly January effect.

Penelitian yang selanjutnya, peneliti merujuk pada Jurnal, Indah Fitriyani, dkk sertaFitri Aprilia Sari yang membahas tentang January effect terjadi akibat adanya perusahaan yang berstrategi untuk memperbaiki laporan keuangannya, dan perbedaan return di January effect. Proksi yang digunakan adalah sama-sama menggunakan return saham, abnormal return, dan trading volume activity. Hasil analisis penelitian menunjukkan bahwa melihat return saham dan abnormal return maka fenomena January effect terjadi di Bursa Efek Indonesia, sedangkan dari trading volume activity, January effect tidak terjadi di Bursa Efek Indonesia. Dalam Hasil analisis data yang menunjukkan terdapat perbedaan return saham pada bulan

${ }^{5}$ Indah Fitriyani dan Maria M. Ratna Sari "Analisisjanuary Effectpada Kelompok Saham Indeks LQ-45 di Bursa Efek Indonesia Tahun 2009-2011"EJurnal Akuntansi Universitas Udayana 2013, hlm. 421433 
Januari dengan bulan selain Januari di pasar modal Indonesia. ${ }^{6}$

Berdasarkan hasil penelitian sebelumnya terdapat perbedaan fokus kajian yang akan diteliti dalam penelitian ini, yakni tentang fokus kajian yeng disajikan, dalam kelanjutan penelitian ini adalah melihat optimalisasi penerapan prinsip-prinsip lembaga keuangan syariah terkait dengan transaksi saham syariah pada saat event studi January Effect periode 2011-2015.

\section{Prinsip-Prinsip Dasar Oprasional Lembaga Keuangan Syariah}

Prinsip Utama yang dianut oleh lembaga keuangan syariah dalam menjalankan kegiatan usahanya adalah:

1) Bebas "MAGRIB"

a. Maysir adalah transaksi yang digantungkan kepada suatu keadaan yang tidak pasti dan bersifat untung-untungan.

b. Gharar adalah transaksi yang objeknya tidak jelas, tidak dimiliki, tidak diketahui keberadaannya, atau tidak dapat di serahkan pada saat transaksi dilakukan.

c. Haram adalah secara bahasa adalah larangan dan penegasan. Larangan ini timbul karena beberapa kemungkinan, yaitu dilarang oleh tuhan dan bias juga karena adanya pertimbangan akal.

${ }^{6}$ Fitri Aprilia Sari danEka Ardhani Sisdyani "Analisis January Effect Di Pasar Modal Indonesia"EJurnal Akuntansi Universitas Udayana 2014, hlm. 237245 d. Riba adalah penambahan pendapatan secara tidak sah antara lain dalam transaksi pertukaran barang sejenis yang tidak sama kualitas, kuantitas, dan waktu penyerahannya atau dalamtransaksipinja-meminjam yang mempersyaratkan nasabah.

e. Bathil adalah tidak sah dalam aktivitas jual beli. Seperti mengurangi timbangan, mencampurkan barang yang rusak diatara barang yang baik untuk mendapatkan keuntungan yang lebih banyak, menimbun barang, menipu atau memaksa. ${ }^{7}$

2) Menjalankan Bisnis dan Aktifitas Perdagangan yang berbasis pada perolehan keuntungan yang sah menurut syariah, yakni: Semua transaksi harus didasarkan pada akad yang diakui oleh syariah, akad adalah perjanjian tertulis yang memuat ijab dan Qabul antara bank dan yang beriisi hak dan kewajiban masing-masing pihak sesuai dengan prinsip syariah.

3) Menyaluskan Zakat, Infak, dan Shadaqah. Lembaga keuangan syariah mempunyai dua peran sekaligus yakni sebagai badan usaha dan badan social.

${ }^{7}$ Andri Soemitra, Bank dan Lembaga Keuangan Syariah, hlm. 38-38 


\section{Landasan Teori}

a. Pasar modal Syariah

Pasar modal syariah adalah pasar modal yang seluruh mekanisme kegiatannya terutama mengenai emiten, jenis efek yang diperdagangkan dan mekanisme perdagangannya telah sesuai dengan prinsip-prinsip syariah. Sedangkan yang di maksud dengan efek syariah adalah efek sebagaimana dimaksud dengan peraturan perundangundangan di bidang pasar modal yang akad, pengelolaan perusahaan, maupun cara penerbitan prinsip-prinsip syariah adalah prinsip yang didasarkan oleh syariah ajaran islam yang penetapannya dilakukan oleh DSN-MUI melalui fatwa.

\section{b. Saham Syariah}

Secara bahasa: jama' dari kata sahmun adalah bagian yang dimiliki, dan saham kata tunggal, jamaknya adalah sahmani dan sahmalu dan saham asalnya dari satu saham yang dikalikan dengan unsur kecurangan yaitu sesuatu yang samar sehingga menjadi banyak, sehingga disebut setiap bagian memiliki satu saham. Dan sari segi epistimologi terdapat 2 pengertian, yaitu:

a. Saham adalah bagian yang di ikutsertakan oleh seorang pemilik saham di dalam syirkah atau perusahaan. Dimisalkan diterbitkan kepada pemegang saham.

b. Dan disebutkan pula bahwa saham adalah bagian yang dibagikan atas beberapa bagian dari pemilik dan perusahaan yangsudahditetapkanbagiannya berdasarkan keiikutsertaan dan dimisalkan sejumlah saham yang dibagi kepada pemilik dana perusahaan berdasarkan keiikutsertaanya. ${ }^{8}$

c. Saham JII

Indeks ini menggunakan 30 saham yang dipilih dari saham-saham yang masuk dalam kriteria syariah(DaftarEfek Syariah yang diterbitkan oleh BapepamLK) dengan mempertimbangkan kapitalisasi pasar dan likuiditas. ${ }^{9}$

d. Konsep Efficient Market Hypotesis $(\mathrm{EMH})$

Fama memberikan beberapa syarat yang harus dipenuhi agar kondisi pasar modal yang efisien dapat dicapai, yaitu:

a. Tidak ada biaya transaksi dalam perdagangan sekuritas.

b. Seluruh informasi yang tersedia dapat diakses oleh semua pelaku pasar secara cuma-cuma. ${ }^{10}$

Profesor Engene Fama membagi efesiensi pasar dalam tiga tingkatan, yaitu: The week Effecient market hypothsis, The Semisttrong effecient market hypothesis, the strong effecient market hypothesis. Diantaranya adalah:

\section{The week Effecient market hypothsis}

${ }^{8}$ Al-Ustadz Dr. Sholih Ibnu Muhammad Bin Sulaiman as Sultan, As-ashum "Hukum dan Dampaknya", (Saudi Arabia, Dar Ibnu Zauji:2016), hlm. 10

${ }^{9}$ Bursa Efek Indonesia,https://www.facebook. $\mathrm{com} /$ notes / indopremier/jenis-jenis-indeks-hargasaham-di-indonesia/10153459940485196/, diakses pada tanggal 24 januari 2017.

${ }^{10}$ Agus Wahyu Pratomo "January Effect”hlm. 12. 
Efesiensi pasar dikatakan lemah (week-from), karena investor di dalam proses pengambilan keputusan jualbeli saham menggunakan data harga dan volume masa lalu. Berdasarkan harga dan volume masa lalu dilakukan berbagai modal analisis teknikal untuk menentukan arah harga-apakah akan naik atau akan turun. Apabila arah harga akan naik, maka akan diputuskan untuk membeli, dan sebaliknya jika arah harga akan turun diputuskan untuk menjual. Analisis teknikal beranggapan bahwa harga saham selalu berulang kembali, setelah naik dalam beberapa hari pasti akan turun dalam beberapa hari berikutnya, kemudian naik lagi dan akan turun lagi dan seterusnya.

\section{The Semisttrong effecient market hypothesis}

Efesiensi pasar dikatakan setengah kuat, karena investor di dalam proses pengambilan keputusan jual-beli saham menggunakan data harga masa lalu, volume masa lalu, dan semua informasi yang di publikasikan- misalnya laporan tahunan, pengumuman bursa, informasi keuangan internasional, peraturan perundangan pemerintahan, peristiwa politik, peristiwa hukum, peristiwa sosial dan sebagainya yang sekiranya dapat mempengaruhi perekonomian nasional.

\section{The strong effecient market hypothesis}

Efesiensi pasar dikatakan bentuk kuat, kerena pengunaan daya yang lebih lengkap yaitu harga masa lalu, volume masa lalu, informasi yang dipublikasikan dan informasi privat yang tidak dipublikasikan secara umum. Contoh informasi privat adalah hasil riset yang diterbitkan sendiri oleh unit kerja unit kerja riset yang ada di dalam perusahan atau dibeli dari lembaga riset pihak luar. $^{11}$

e. Return

Return merupakan hasil yang diperoleh dari investasi. Return dapat berupa return realisasian yang sudah terjadi atau return ekspektasi yang belum terjadi tetapi yang di harapakan akan terjadi di masa depan. Return realisasi merupakan return yang telah terjadi. Return realisasian dihitung menggunakan data historis. Return realisasi penting karena digunakan dasar penentuan return ekspektasi dan risiko di masa depan. Di konteks studi peristiwa, return realisasian merupakan return sesungguhnya yang terjadi. Diantara return-return sesungguhnya adalah:Return Total merupakan return keseluruhan dari investasi dalam suatu periode. Return total sering disebut return saja. Relatif Return merupakan perhitungan yang digunakan untuk mengukur total return bernilai negatif atau positif.Logaritma Return merupakan perhitungan yang digunakan untuk mengukur return saham tidak berdistribusi normal.Return sesuai inflasi merupakan return riel atau return sesuai inflasi.

\section{f. Return Normal}

\footnotetext{
${ }^{11}$ Mohammad Samsul, Pasar Modal dan Manajemn Fortofolio, (Jakarta:Erlangga:2015), hlm. 227.
} 
Studi peristiwa menganalisis return taknormal dari sekulitas yang mungkin terjadi di sekitar pengumuman dari suatu peristiwa. Return teknormal atau return kelebihan merupkan kelebihan dari return yang sesungguhnya terjadi terhadap return normal. Dengan demikian return normal adalah selisih antara return sesungguhnya yang terjadi dengan return ekspektasi. ${ }^{12}$

\section{g. Return Taknormal}

Return taknormal merupakan selisih antara return sesunguhnya dengan return normal. Return taknormal perlu dihitung tiap-tiap tanggal (umumnya tiap hari pada periode jendela untuk masing-masing sekuritas. Return taknormal untuk masing-masing sekuritas ini kemudian perlu di rerata secara cross-sectional untuk di dapatkan rerata return taknormal untuk tiap-tiap tanggal di periode jendela. Kadangkala rerata return taknormal ini perlu diakumulasi sepanjang periode jendela untuk mengetahui total tambahan kekayaan akibat dari peristiwa yang terjadi. Kadangkala akumulasi dilakukan di periode sebelum tanggal peristiwa dan setelah tanggal peristiwa. Kedua akumulasi ini kemudian di bandingkan untuk menguji perubahan kekayaan sebelumdansesudahnyaterjadiperistiwa sepanjang jendela perusahaan.

h. Menghitung return taknormal

Return taknormal dapat dihitung dengan menggunakan:

$$
R_{i, t}=R T N_{i, t-\mathrm{E}}\left(R_{i, t}\right)
$$

${ }^{12} J$ Jogiyanto "Studi peristiwa" (Yogyakarta:BPFE:Y ogyakarta:2010), Hal. 63-69
Notasi:

$R T N_{i, t}=$ return taknormal (abnormal return) sekuritas ke-i pada periode peristiwa ke-t;

$R_{i, t}=$ return sesungguhnya yang terjadi untuk sekuritas ke-i pada periode peristiwa ke-t.

$E\left[R_{i, t}\right]=$ return ekspektasi sekuritas ke-i pada periode peristiwa ke-t.

i. Event Study

Event study merupakan metodologi riset para ahli ekonomi untuk mengukur pengaruhdari suatu kejadian ekonomi terhadap value of the firms dengan menggunakandata akuntansi ataupun data keuangan di pasar.

j. Model Krangka Pemikiran dan Pengembangan Hipotesis

January Effect: Suatu kondisi yang terjadi di pasar modal dimana pada bulan Januari cenderung rata-rata pengembalian return bulanannya lebih tinggi dibandingkan dengan bulanbulan lainnnya.

H1: Terdapatperbedaanoptimalisme prinsip-prinsip LKS non-bank sebelum January Effectterhadap abnormal return saham syariah JII yang diperdagangkan di pasar modal Indonesia.

H2: Terdapat perbedaan optimalisasi prinsip- prinsip LKS sesudah January Effect terhadap abnormal return saham syariah JII di pasar modal Indonesia.

Berdasarkan latar belakang masalah serta kajian teori maupun kajian-kajian penelitian yang relevan, adapun krangka 
pemikiran yang tepat dan lebih jelasnya akan dijabarkan dalam bentuk gambar di bawah ini, yakni tentang January Effect terhadap ukuran Abnormal return saham syariah JII di pasar modal Indonesia adalah sebagai berikut:

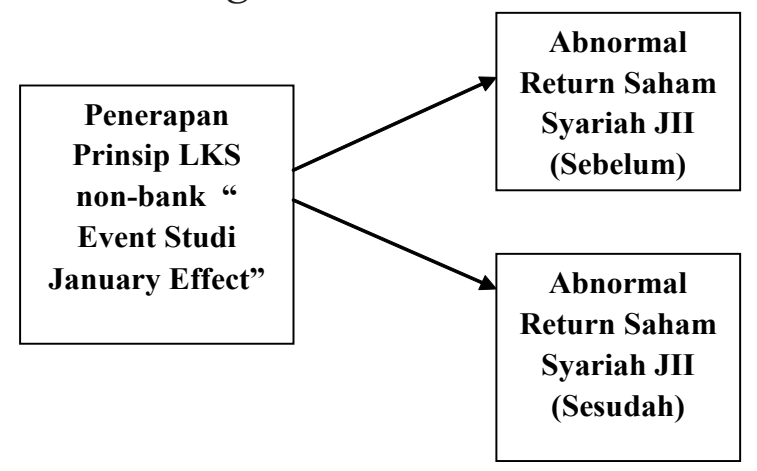

\section{METODOLOGI PENELITIAN}

\section{Populasi dan Pemilihan Sampel}

Populasi yang diambil dalam penelitian ini adalah semua perusahaan yang termasuk dalam saham JII di BEI untuk efek syariah dari periode January 2011 sampai periode 2015. Sampel yang akan diambil adalah emiten atau perusahan yang konsisten menerbitkan serta masuk katagori saham syariah selama lima tahun terakhir dari tahun 2011-2015. Saham konsisten yang dijadikan sampel dalam saham katagori syariah terdiri dari 20 saham JII.

\section{Jenis Penelitian}

Jenis pendekatan penelitian dalam paper ini menggunakan metode event study untuk menganalisis pengaruh Januari efek terhadap perilaku saham syariah saham JII di pasar modal Indonesia.

\section{Sumber data}

Data dalam penelitian ini adalah berupa data sekunder secara penuh yang diperoleh dari situs BEI, khusunya situs www.yahoo.finance di Indonesia untuk periode Januari 2011-Desember 2015 yang terdiri dari: Harga Saham Penutupan harian seluruh perusahaan sampel yang tercatat di BEI di pasar modal Indonesia khususnya Jakarta Islamic indeks (JII).

\section{Teknik Analisis dan Pengujian Hipotesis}

Uji analisis kuantitatif menggunakan uji statistik dengan bantuan program SPSS 21. Data dianalisis dengan analisis uji Statistik diskriptif, uji Normalitas, dan uji t paired test.

\section{E. ANALISIS DATA DAN PEMBAHASAN}

\section{Hasil Uji Statistik Deskriptif}

Tabel 1.1

\section{Hasil Abnormal Return Saham JII} 2011-2015

\begin{tabular}{|l|l|l|}
\hline Hari Ke & $\begin{array}{l}\text { Abnormal Return } \\
\text { Saham JII }\end{array}$ & \\
\hline $\mathrm{t}-7$ & $-0,0007$ & 0,0725 \\
\hline $\mathrm{t}-6$ & 0,0112 & 0,0269 \\
\hline $\mathrm{t}-5$ & $-0,9902$ & 0,0319 \\
\hline $\mathrm{t}-4$ & 0,0883 & 0,0316 \\
\hline $\mathrm{t}-3$ & 0,0010 & 0,0605 \\
\hline $\mathrm{t}-2$ & $-0,0001$ & 0,0931 \\
\hline $\mathrm{t}-1$ & $-0,0005$ & 0,0711 \\
\hline $\mathrm{t}+1$ & 0,2034 & 0,0000 \\
\hline $\mathrm{t}+2$ & 0,1849 & 0,0000 \\
\hline
\end{tabular}




\begin{tabular}{|l|l|l|}
\hline$t+3$ & $-0,1780$ & 0,0000 \\
\hline$t+4$ & $-0,0008$ & 0,0691 \\
\hline$t+5$ & 0,2056 & 0,0000 \\
\hline$t+6$ & $-0,0035$ & 0,0059 \\
\hline$t+7$ & $-0,0065$ & 0,0013 \\
\hline
\end{tabular}

Sumber:Ouput SPSS Versi 21

Berdasarkan Tabel 1.1. menjelaskan bahwa hasil pengujian statistik diskriptif untuk rata-rata abnormal return sebelum dan sesudah Januari Effcet selam lima tahundaritahun2011-2015. Menunjukan bahwa nilai rata-rata tertinggi sebelum January effect untuk perusahaan JII pada t-4 dengan nilai sebesar 0,0883 dengan nilai signifikan 0,0316 karena nilai $<0,05$ maka tidak signifikan secara statistik, Rata-rata nilai tertinggi sesudah January Effect untuk perusahaan JII pada $\mathrm{t}+5$ sebesar 0,2056dengan nilai signifikan 0,0000 karena nilai $<0,05$ maka tidak signifikan secara statistik. Nilai ratarata terendah sebelum January Effect untuk perusahaan JII adalah pada $\mathrm{t}-2$ sebesar 0,0001 dengan nilai signifikan $0,0931>0,05$ maka signifikan secara statistik. Sesudah January Effect nilai rata-rata terendah perusahaan JII pada $\mathrm{t}+4$ sebesar 0,008 dengan nilai signifikan $0,0691>0,05$ maka signifikan secara statistik.. Rata-rata nilai tertinggi dan terendah antara sebelum dan sesudah January Effect selama lima tahun dari tahun 2011-2015 dapat dilihat dengan nilai signifikan dalam grafik di bawah ini.

Tabel 1.2

Hasil Analisis Statistik Deskriptif Abnormal Return Saham JII Sebelum dan Sesudah 2011-2015

\begin{tabular}{|l|c|c|c|c|c|}
\hline \multicolumn{2}{|l|}{ Descriptive Statistics } \\
\hline & N & Minimum & Maximum & Mean & $\begin{array}{c}\text { Std. } \\
\text { Deviation }\end{array}$ \\
\hline $\begin{array}{l}\text { Abnormal } \\
\text { Return } \\
\text { Sebelum JII }\end{array}$ & 14 &,- 8957 & 8,773 &, 0114 &, 33385 \\
\hline $\begin{array}{l}\text { Abnormal } \\
\text { Return } \\
\text { Sesudah JII }\end{array}$ & 14 & $-989,3$ & 1,044 & $-26,76$ & 160,88 \\
\hline Valid N (listwise) & 14 & & & & \\
\hline
\end{tabular}

Berdasarkan hasil perhitungan yang disajikan dalam tabel 1.2 diatas, selama pengamatan lima tahun dari tahun 20112015, rata-rata Abnormal return saham JII sebelum sebesar 0,114 dengan standar deviasi (SD) sebesar ,33385. Rata-rata 
Abnormal return saham JII sesudah sebesar $-26,76$ dan rata-rata abnormal return saham BISNIS 27 sesudah sebesar -27,09 dengan standar deviasi untuk saham JII sesudah sebesar 160,88. Hasil tersebut bisa disimpulkan terjadi peyebaran nilai yang kurang baik, karna standar deviasi untuk Abnormal return saham JII sesudah terjadi atau seminggu awal bulan Januari dan sesudah peristiwa biasanya terjadi peristiwa January Effect lebih besar dari standar deviasi sebelum January Effect.

\section{Hasil Uji Normalitas}

Tabel 1.3

Pengujian Normalitas Abnormal Return Saham JII Periode 2011-2015

\begin{tabular}{|l|l|l|}
\hline \multicolumn{2}{|l|}{ One-Sample Kolmogorov-Smirnov Test } \\
\hline \multicolumn{2}{|l|}{ AbnormalReturnJll } \\
\hline N & 336 \\
\hline \multirow{3}{*}{ Normal Parameters, $\mathrm{b}$} & Mean & $-4,710918271812$ \\
\cline { 2 - 3 } & Std. Deviation & 1,1899818065859 \\
\hline \multirow{4}{*}{ Most Extreme Differences } & Absolute &, 076 \\
\cline { 2 - 3 } & Positive &, 076 \\
\cline { 2 - 3 } & Negative &,- 075 \\
\hline Kolmogorov-Smirnov Z & & 1,402 \\
\hline Asymp. Sig. (2-tailed) & 0,039 \\
\hline a. Test distribution is Normal. & \\
\hline b. Calculated from data. & \\
\hline
\end{tabular}

Dari hasil perhitungan abnormal return saham syariah diatas, bisa dijabarkan bahwa abnormal return saham JII sebesar 0,039 lebih besar dari 0,05. Bisa disimpulkan bahwa abnormal return saham JII untuk kategori saham yang berbasis syariahadalah normal.

\section{Hasil Analisis (Uji Hipotesis)}

Hipotesis ini akan menguji apakah terdapat abnormal return saham JII untuk mewakili saham syariah selama satu minggu atau 7 hari sebelum bulan Januari dan 7 hari awal bulan Januari, diukur dengan t-7,t-6, t-5, t-4, t-3, t-2, $\mathrm{t}-1$ dan $\mathrm{t}+1, \mathrm{t}+2, \mathrm{t}+3, \mathrm{t}+4, \mathrm{t}+5, \mathrm{t}+6$, $\mathrm{t}+7$ dengan mengunakan metode ini akan diketahui ada tidaknya perbedaan Abnormal Return saham yang terjadi di sekitar peristiwa January Effect.

Menentukan ada tidaknya perbedaan antara abnormal return saham JII sebelum dan sesudah January Effect, dilihat dari nilai $\mathrm{t}$ dan sig (2-tailed). Dengan melihat penentuan penerimaan dan penolakan adalah sebagai berikut:

1. Jikathitung $<$ ttabel, atauprobabilitas $>0,05$, maka H1 ditolak.

2. Jika thitung $>$ ttabel, atau profabilitas $<$ 0,05, maka H1 Diterima.

\section{Hasil Uji Hipotesis}

Pengujian Hipotesis 1, terdapat perbedaan pengaruh sebelum dan sesudah January Effect terhadap return dan abnormal return saham syariah atau Jakarta Islamic Indeks (JII), yakni pada periode $\mathrm{t}-1$ dan $\mathrm{t}+1, \mathrm{t}-2$ dan $\mathrm{t}+2$, $\mathrm{t}-3$ dan $\mathrm{t}+3, \mathrm{t}-4$ dan $\mathrm{t}+4, \mathrm{t}-5$ dan $\mathrm{t}+5, \mathrm{t}-6$ dan $\mathrm{t}+6, \mathrm{t}-7$ dan $\mathrm{t}+7$ selama 5 tahun dari tahun 2011-2015. 


\section{Uji Abnormal Retun saham JII}

Tabel 1.4

Hasil Uji t-paired test Abnormal Return Saham JII periode 2011-2015

\begin{tabular}{|c|c|c|c|c|c|}
\hline \multicolumn{2}{|c|}{} & Mean & N & Std. Dev. & Std. Error Mean \\
\hline Pair 1 & t-1 & $-0,0007$ & 100 & 0,0202 & 0,0020 \\
\hline & t+1 & 0,2034 & 100 & 0,4004 & 0,0400 \\
\hline Pair 2 & t-2 & 0,0112 & 100 & 0,1008 & 0,0100 \\
\hline & t+2 & 0,1849 & 100 & 0,3826 & 0,0382 \\
\hline Pair 3 & t-3 & $-0,9902$ & 100 & 0,9892 & 0,9892 \\
\hline & t+3 & $-0,1780$ & 100 & 0,3819 & 0,3819 \\
\hline Pair 4 & T-4 & 0,0883 & 100 & 0,8774 & 0,0877 \\
\hline & T+4 & $-0,0008$ & 100 & 0,0215 & 0,0021 \\
\hline Pair 5 & t-5 & 0,0010 & 100 & 0,0192 & 0,0019 \\
\hline & t+5 & 0,2056 & 100 & 0,4014 & 0,0401 \\
\hline Pair 6 & t-6 & $-0,0001$ & 100 & 0,0178 & 0,0017 \\
\hline & t+6 & $-0,0035$ & 100 & 0,0186 & 0,0018 \\
\hline Pair 7 & t-7 & $-0,0005$ & 100 & $-0,0152$ & 0,0015 \\
\hline & t+7 & $-0,0065$ & 100 & 0,0260 & 0,0026 \\
\hline
\end{tabular}

Paired Samples Test

\begin{tabular}{|c|c|c|c|c|c|c|c|c|c|}
\hline & & \multicolumn{5}{|c|}{ Paired Differences } & \multirow{3}{*}{$t$} & \multirow{3}{*}{$d f$} & \multirow{3}{*}{$\begin{array}{c}\text { Sig. } \\
\text { (2-tailed) }\end{array}$} \\
\hline & & \multirow[t]{2}{*}{ Mean } & \multirow[t]{2}{*}{ Std. Dev. } & \multirow[t]{2}{*}{$\begin{array}{l}\text { Std. Error } \\
\text { Mean }\end{array}$} & \multicolumn{2}{|c|}{$\begin{array}{l}95 \% \text { Confidence } \\
\text { Interval of the } \\
\text { Difference }\end{array}$} & & & \\
\hline & & & & & Lower & Upper & & & \\
\hline Pair 1 & $t-1-t+1$ & $-0,2041$ & 0,4019 & 0,0401 & $-0,2839$ & $-0,1244$ & $-0,50800$ & 99 & 00,000 \\
\hline Pair 2 & $t-2-t+2$ & $-0,1737$ & 0,4000 & 0,0400 & $-0,2530$ & $-0,0943$ & $-0,4343$ & 99 & 00,000 \\
\hline Pair 3 & $t-3-t+3$ & 0,1681 & 0,3990 & 0,3990 & 0,8898 & 0,2473 & 0,4214 & 99 & 00,000 \\
\hline Pair 4 & $t-4-t+4$ & 0,0892 & 0,8807 & 0,0880 & $-0,0855$ & 0,2640 & 0,1013 & 99 & 0,0313 \\
\hline Pair 5 & $t-5-t+5$ & $-0,2046$ & 0,4040 & 0,0404 & $-0,2848$ & $-0,1244$ & $-0,5065$ & 99 & 00,000 \\
\hline Pair 6 & $t-6-t+6$ & 0,0034 & 0,0244 & 0,0024 & $-0,0014$ & 0,0082 & 0,1393 & 99 & 0,0167 \\
\hline
\end{tabular}




\begin{tabular}{|l|c|c|c|c|c|c|c|c|c|}
\hline Pair 7 & $\mathrm{t}-7-\mathrm{t}+7$ & 0,0601 & 0,0315 & 0,0031 & $-0,0002$ & 0,0122 & 0,1905 & 99 & 0,0060 \\
\hline
\end{tabular}

Sumber: Output SPSS Versi 21

Berdasarkan Tabel 1.4. menjelaskan bahwa hasil pengujian dengan menggunakan metode uji paired sampel test, abnormal return saham pada $t-1$ dan $\mathrm{t}+1$ menunjukkan nilai rata-rata sebesar 0,2041, nilai $t$ sebesar $-0,5080$ dan nilai signifikasi sebesar 0,0000 . Abnormal Return saham pada t-2 dan $\mathrm{t}+2$ menunjukkan nilai rata-rata sebesar -0,1737, dan nilai $t$ sebesar 0,4343 dan nilai signifikasi sebesar 0,0000 . Abnormal Return saham pada t-3 dan $\mathrm{t}+3$ menunjukkan bahwa nilai rata-rata sebesar 0,1681 dengan nilai t 0,4214 dan nilai signifikasi sebesar 0,0000. Abnormal Return saham $\mathrm{t}-4$ dan $\mathrm{t}+4$ menunjukkan nilai rata-rata sebesar 0,0892 dan nilai $t$ sebesar 0,1013 dengan nilai signifikasi sebesar 0,0313. Abnormal Return saham $\mathrm{t}-5$ dan $\mathrm{t}+5$ menunjukkan bahwa nilai rata-rata sebesar $-0,2046$ dan nilai $t$ sebesar -0,5065 dengan nilai signifikasi sebesar 0,0000. Abnormal Return saham $\mathrm{t}-6$ dan $\mathrm{t}+6$ menunjukkan bahwa nilai rata-rata sebesar 0,0034 dan nilai $t$ sebesar 0,1393 dengan nilai signifikasi sebesar 0,0167. Abnormal Return saham $\mathrm{t}-7$ dan $\mathrm{t}+7$ menunjukkan nilai rata-rata sebesar 0,0060 dan nilai t sebesar 0,1905 dengan nilai signifikasi sebesar 0,0060. Seperti yang di bahas sebelumnya bahwa nilai signifikasi yang diatas 0,05 menunjukkan tidak adanya perbedaan yang signifikan, sehingga hasil abnormal return sebelum dan sesudah January Effect menunjukkan bahwa nilai t-1 dan $\mathrm{t}+1$ sampai $\mathrm{t}-6$ dan $\mathrm{t}+6$ menunjukkan nilai yang diterima karena menghasilkan nilai signifikasi kurang dari 0,05, artinya ada perbedaan secara signifikanselama 6 hari baik sebelum dan sesudah January Effect. Hasil penelitian ini bertentangan dengan Prinsip oprasional lembaga keuangan baik bank maupun nonbank, yang menyebutkan bahwa: Pelaksanaan transaksi harus dilakukan menurut prinsip kehati-hatian serta tidak diperbolehkan melakukan spekulasi dan manipulasi yang di dalamnya mengandung unsur dharar, gharar, riba, maisir, risywah, maksiat dan kezhaliman, seperti Insider trading, yaitu memakai informasi orang dalam untuk memperoleh keuntungan atas transaksi yang dilarang, Menimbulkan informasi yang menyesatkan, Ihtikar (penimbunan), yaitu melakukan pembelian atau dan pengumpulan suatu Efek Syariah untuk menyebabkan perubahan harga Efek Syariah, dengan tujuan mempengaruhi Pihak lain.

Fenomena Event Studi January Effect dalam pembahasan kajian teori Menurut Sharpe Terdapat tiga penyebab terjadinya January Effect, yaitu: 1) taxloss selling, 2) window dressing, 3) small stock's beta. Tax-loss selling merupakan suatu fenomena dengan menjual saham-saham yang hasilnya buruk dengan tujuan untuk memperbaiki laporan keuangannya yang nantinya akan berdampak kepada pengurangan pajak pada akhir tahun. Sedangkan pada window dressing, tidak jauh berebeda 
dengan tax-loss selling pada dasarnya hal yang dilakukannya adalah sama yaitu dengan menjual saham-saham dengan kerugian besar, namun letak perbedaannya adalah hal ini dilakukan bukan untuk tujuan pengurangan pajak melainkanmemperbaikiportofolioakhir tahun yang dimiliki perusahaan agar terlihat baik. Untukstock's beta itu sendiri adalah kecenderungan yang terjadi ketika pada bulan Januari, perusahaan kecil lebih memberikan tingkat return yang lebih tinggi dibandingkan dengan perusahaan besar. ${ }^{13}$ Berbeda $\mathrm{t}-7$ dan $\mathrm{t}+7$, menunjukan nilai ditolak karena di atas 0,05 , sehingga sebelum dan sesudah January Effect tidak ada perbedaan pengaruh January Effect yang terjadi, sehingga $\mathrm{t}-7$ dan $\mathrm{t}+7$ tidak menunjukan Abnormal Return yang tinggi, dan normal seperti hari-hari kerja biasa.

\section{F. KESIMPULAN DAN SARAN}

Fenomena Event Studi January Effect dalam pembahasan kajian teori Menurut Sharpe Terdapat tiga penyebab terjadinya January Effect, yaitu: salah satunya adalah tax-loss selling. Salah satu penyebab terjadinya abnormal return pada event studi january effect bertentangan dengan dengan prinsip dasar lembaga keuangan syariah tentang Bebas Maysir, Gharar, haram, riba, bathil ( MAGRIB), menjalankan bisnis dan aktivitas perdagangan yang berbasis pada perolehan keuntungan yang sah

\footnotetext{
${ }^{13 I}$ ndah Fitriyani dan Maria M. Ratna Sari "Analisis January Effectpada Kelompok Saham Indeks LQ-45 di Bursa Efek Indonesia Tahun 2009-2011”,E-Jurnal Akuntansi Universitas Udayana 2013, hlm. 421- 433.
}

menurut syariah, menyalurkan zakat, infak dan shadaqah.

Saran yang dapat penulis harapkan untuk investor ataupun pelaku bisnis lainnya adalah prinsip-prinsip lembaga keuangansyariahbaikdalambentukbank maupun non bank lebih di perhatikan, karena anomaly-anomaly yang sering terjadi di pasar modal baik syariah maupun konvensional berpengaruh terhadap efesiensi pasar, sehingga pasar tidak lagi menyediakan pasar yang sehat. Bagi peneliti selanjutnya agar penelitian ini lebih dikembangkan bukan hanya tinjauan untuk prinsip syariah dari segi anomaly, akan tetapi dari segi investasiinvestasi lainnya.

\section{DAFTAR PUSTAKA}

Jogiyanto, Studi peristiwa, Yogyakarta: BPFE, 2010.

Sometri, Andri, Bank Dan Lembaga Keuangan Syariah, Jakarta:Kencana, 2009.

Sugiyono,Metode Penelitian Bisnis. Pendekatan Kuantitatif, Kualitatif dan R\&D, Bandung: Alfabeta, 2013.

Fitriyani, Indah dan Ratna, Maria M. "AnalisisJanuary Effectpada Kelompok Saham Indeks LQ-45 di Bursa Efek Indonesia Tahun 2009-2011” E-Jurnal Akuntansi Universitas Udayana. 2013.

Hartono, Jogiyanto (2009:195) dalam Jurnal Devita Nursanti "Analisis Perbedaan January Effect Dan Rogalsky Effect Pada Perusahaan 
Yang Tergabung Dalam Jakarta Islamic Index Di Bursa Efek Indonesia Tahun2011-2013"Jurnal Program Studi Akuntansi, Fakultas Ekonomi Universitas Slamet Riyadi Surakarta Vol. 11 Edisi Khusus Desember 2015.

Wiwit Rahyuningsih "Pengaruh January Effect Dan Size Effect Terhadap Return Saham Di JII Tahun 20102013" Jurnal Fakultas Ekonomi Jurusan Manajemen, UIN Malang. 2013.

Sharpe et al, 1995:81, dalam Jurnalnya "Fitri Aprilia Sari, Analisis January Effect Di Pasar Modal Indonesia”,Ejurnal Akuntansi, Universitas Udayana Fakultas Ekonomi dan Bisnis Universitas Udayana (Unud), Bali, Indonesia, 2014.

Bursa Efek Indonesia, http:// informasipedia.com/investasi/ $\mathrm{s}$ a h a $\mathrm{m} / \mathrm{d}$ a f t a r - s a h a m indeksjii/138-daftar-sahamindeks-jiidesember-2014-mei2015.html, Dipublikasikan: 24 April 2015, diambil pada tanggal 24 Januari 2017.

Bursa Efek Indonesia, https:// w w w. f a c e b o o k. c o m / notes/indopremier/jenis jenis-indeks-harg saham-di Indonesia/ 10153459940485196/, diakses pada tanggal 24 Januari 2017.
Karina Maliasari "Pengaruh January Effect Dan Rogalski Effect Terhadap Abnormal Return Saham Dan Trading Volume Activity (Studi Pada Perusahaan LQ45 yang Terdaftar di Bursa Efek Indonesia)"Tesis, Fakultas Ekonomi dan Bisnis, Universitas Brawijaya Malang 2013.

Devita Nursanti, "Analisis Perbedaan January Effect Dan Rogalsky Effect Pada Perusahaan Yang Tergabung Dalam Jakarta Islamic Index Di Bursa Efek Indonesia Tahun 2011-2013"Jurnal Akuntansi dan Sistem Teknologi InformasiFakultas Ekonomi Universitas Slamet Riyadi Surakarta. Vol. 11 Edisi Khusus Desember 2015.

Fitri Aprilia Sari danEka Ardhani Sisdyani "Analisis January Effect Di Pasar Modal Indonesia”E-Jurnal Akuntansi Universitas Udayana 2014.

Al-Ustadz Dr. Sholih Ibnu Muhammad Bin Sulaiman as Sultan, As-ashum "Hukum dan Dampaknya", Saudi Arabia, Dar Ibnu Zauji:2016.

MohammadSamsul, Pasar Modal dan Manajemn Fortofolio, Jakarta:Erlangga:2015. 